\title{
INCREASING THE STUDENTS' SPEAKING ABILITY THROUGH BAMBOO DANCING METHOD
}

\author{
Amar Ma'ruf, Rika Rahim \\ English Education Department, Faculty of Teacher Training and Education \\ Muhammadiyah University of Makassar
}

\begin{abstract}
The objective of this research was to find out the improvement of the students' fluency and speaking fluency through bamboo dancing pairs and to find out the improvement of the students' fluency in speaking through bamboo dancing pairs. The researcher used a class Action Research (CAR). The researcher had conducted two cycles, where each cycle consists of four meetings. It employed speaking test as instrument. The number subject of the research is 24 students in class V11. A. The researcher took data of real from the school to know the students' speaking fluency. The research findings indicated that the use of Bamboo dancing Method increased the students' speaking fluency. From the table 1 indicated that there was increase the students' speaking fluency from cycle I to cycle II, where as in cycle I the students' achievement was 5.5 and in cycle II the students' achievement was 7.2. Then from the table two indicated that there was increase the students' speaking fluency from cycle I to cycle II, where as in the cycle I the students' achievement was 5.9 and in cycle II the students' achievement was 7.8. From this findings, the research made conclusion that by using Bamboo Dancing method could improve the students' motivation in speaking fluency and make the students' active to speak in learning process.
\end{abstract}

Keyword: Increasing, speaking, ability, bamboo, dancing, method

English is one of tools in communication, not only in oral but also in writing. The national education department has made competence standard in curriculum 2004, states that the students in Indonesia have to have capability in understanding and giving information, idea, séance, and also improving knowledge, technology, and culture by using English. Therefore English not only has function as tool in communication to access the information but also as a tool to exchange information and sense of English esthetic in English culture. There are four skills language in junior high school namely reading, listening, writing, and speaking. Especially speaking skill, many students considered that learning speaking as a difficult subject. This difficulty is caused by psychology factor of the students and lack of teachers' creativity in teaching speaking English subject in junior high school the students at the Interactive English Task at the first grade of SMPN 4 Biringbulu still cannot communicate by using English.

The students at Interactive English Task at the first grade of SMPN 4 Biringbulu still cannot use their English in communication because they considered 
that English subject is bored and scare. Therefore, their scores in speaking are low. As value of observation in the classroom the students' have score 56 especially speaking skill. This score is categorizing poor, while the standard speaking in curriculum is 6.5. Based on statement above, the researcher would like to introduce an approach that could be used by teachers to improve their teaching approach (in teaching English specially) and can help the students to have better understanding in learning English speaking, it is Interactive English Task. The researcher wants to achieve the score 7 target in speaking subject by applying this method. Using Interactive English Task will be helpful the students to speak up. In this case, the teacher introduces a situation which contextualizes the language to be thought then presented, next the students practice the new language in a control way and then students are encouraged to use the new language in a freeway either for their own purpose and meanings or in a similar context introduced by the teacher.

The finding of the research is expected to provide contribution and recommendation in identifying some problems faced by the English teachers in teaching English, especially in speaking proficiency. It is expected to motivate the students in learning English and the result of this research is expected to give contribution theoretically and practically in the development in English teaching.

\section{CONCEPTS OF BAMBOO DANCING}

Bamboo dancing is a method to give some relevant information for the students' in the classroom to learn the next material. The use of Bamboo Dancing method the teacher hopes that all of the students' can understand the materials that have given to them. It is a good way to for the students' to develop their confidence in speaking activity in the classroom.

Bamboo dancing method used to build the student teamwork in learning activity especially when they are in the groups. The teacher focus to makes all of the students' active in discussion and share many information about the topics.

In this method, the teachers hope to make a new situation and method for their students'. A good management can help the teachers to achieve in this method. Listed below are some of the ways to use bamboo-dancing method, the steps are:

a. At the first meeting the teacher introduce the topic before, it can help easy to understand the material. 
b. Write the topic and discuss with the students' about the topic. Ask the students' some question that relevant with the topic. This step the students more easy to take a new materials.

c. Separate the students into two groups, if there are 40 students in the class means that 20 students each group.

d. Then 20 students in the first group separate again into two groups, 10 students' each group called first pairs ask them to stand face to face.

e. Then the teacher gives them topics to discuss about it and every group with different topics.

f. After discuss about the topic the 20 students who stand in the group walk around get a new couple and share information about the topic, the activity will be end when the student get their first couple. Their move to share information it is like a bamboo dance.

g. The result of discussion in main group presented in front of class and the teacher facilitates them to asking and question activities. The main point of this activity to get new information and the result become knowledge for all.

\section{SPEAKING ACHIEVEMENT}

\section{Speaking}

Speaking is meaning tools communication to other or speaking is way to bring a massage from one person to another interact with them. Communication will be not running well without speaking and it is essential way which the speaker can express themselves through the language, communication is collaborate venture in which the interlocutors negotiate meaning in order to achieve their communication ends (Numan, 1991:47). Harmer (1991:46) states that communication between human is an extremely complex and ever changing phenomenon and it is my attention to examine all.

According to Brawan in (Samsu Alam, 2007) speaking is an interactive process of constructing meaning that involves producing and receiving a processing information. Speakers require that speakers not know how to produce specific point of language such as grammar, pronunciation, but also that understand when, why, and what ways to produce language. Based on the definition above, the writer can conclude that speaking is the proficiency to express our idea, opinion about all of 
thing around us through our sound system and good understanding of the speaker and the listener.

\section{Skill}

Hornby (1995) defined skill is the mental or physical capacity, power or skill required to do something. Roach in Samsu Alam (2007) stated the skill is the level of success full performance of the objects of measurement on the variable. Based on the definition above, the writer can conclude that skill is proficiency or capacity that required doing something or something that can be used to measure the successful of someone, it can be natural or acquired.

\section{ELEMENTS OF SPEAKING}

\section{Pronunciation}

Pronunciation is an act or result of production the sound of speech including articulation vowel formation, accent and inflection. Often with reference to some standard of contents or accept proficiency. The concept of "pronunciation" may be said to include:

a) The sound of the language

One their own the sound of language may well meaningless. If you said /t/ (the line show that this is phonetic script) a few times, e.g. tu, it will not mean very much English. Neither will be sounds $/ \mathrm{k} /, / \mathrm{a} /$, or $/ \mathrm{s} /$ but if we put all these are sound together a certain order we and up the word catch and does mean something.

b) Stress

Native speaker of language unconsciously know about the stress and how it works, they know which syllables of words are stressed and they know how to use stress, to change the meaning of phrase, sentences and question.

c) Intonation

Intonation is clearly important item and component user of language recognize what meaning it has and can change the meaning of word they through using it in different ways, when we taught English language, student's need it use rhythms and stress correctly if they are to be understood.

\section{Vocabulary}

a. What is vocabulary? 
According to Webster's near world print dictionary (Webster: 1983:2946), vocabularies are list of word etc as dictionary or glossary and all of words used a language or by a person group etc. According to Longman dictionary of contemporary English (Longman 1995:240) vocabularies are all words someone knows, learners or user the words in particularly language a list of words with explanation of their meaning, in a book for learning foreign language.

b. Types of vocabulary

Harmer (1991:159) distinguishes two types of vocabulary namely active vocabulary and passive vocabulary. According to him, active vocabulary is that the students have learned and which they are expected to be able to use. On the other hand, passive vocabulary refers to words that the students will recognize when they met but will probably not be divided in to four kinds as follows:

1) Oral vocabulary consists of words actively used in speech. These are the words that come readily to one's conversation. The more often a person utters words the words the more readily it will come to his tongue.

2) Writing vocabulary is the words that come readily to one's finger vocabulary

3) Listening vocabulary is the stock of words to which one responds with meaning and understood in speaking of other

4) Reading vocabulary is the words that one response in writing of others

\section{Grammar}

Grammar whose subject matter is the organization of words in to variables communication, often representing many layers of structure, such as phrase sentences, and complete utterance (Ba'dulu, 2001:15). As the framework to find sentences productively needed. The fact however shows that the learners' mastery or English structure is skill less as found out by some previous researches.

\section{Fluency}

Fluency refer to able to speak to write smoothly, easy reading, to an easy flow is word or able communication with base is suggested the flow an accomplished speaker and writer, it is usually a tern of commendation. According to hornby (1995:122) stated that fluency is the quality or condition of being fluent. Fluency is highly complex notion relate mainly to smoothness of continuity in discourse. It includes a consideration of how sentence are connected, how sentence 
patterns vary in word order and omit elements of structure and also certain aspects of the prosody of discourse.

\section{B. The Characteristics of A Successful Speaking Activity}

According to Penny Ur (1996: 120), Speaking for leaner is not easy, at least four criteria should be covered by the learner in speaking activity. They are:

Learners talk a lot. As much as possible of the period of time allotted to the activity is in fact occupied by learner talk.

Participation is even. Classroom discussion is not dominated by a minority of talkative participants: all get a chance to speak, and contributions are fairly evenly distributed.

Motivation is high. Learners are eager to speak: because they are interested in the topic and have something new to say about it, or because they want to contribute to achieving a task objective.

Language is of an acceptable level. Learners express themselves in utterances that are relevant, easily comprehensible to each other, and of an acceptable level of language accuracy.

In conceptual frame work above, explain the using Interactive English Task to improve the students' speaking proficiency, in procedure the teacher introduce the material by using Attractive English task And then examine the students' speaking proficiency by ask to the students to retell their experience and describing the picture.

\section{RESEARCH METHOD}

Before doing the cycle, the researcher gave the diagnostic test to know the students' speaking proficiency at the first Grade of SMPN 4 Biringbulu. The researcher used classroom action research (CAR). had stages those were: Planning, Action, Observation, Evaluation or Reflection. The researcher held two cycles each cycle consistsed of two meeting. They were first and second cycle and each cycle was the series of activity, which had close relation. Where, the realization of the second cycle was continuing and repairing from the first cycle described as follow: 


\section{Cycle I}

\section{Planning}

a. In this section, the teacher prepared the material about speaking gave to the students.

b. The teacher made lesson planning for the first meeting, the second meeting, the third and the forth meeting about speaking material.

c. Making checklist observation to observe the students'activity.

d. Making research instrument.

\section{Action}

In this section the researcherr conducted two cycles, where each cycle consistsed of four meeting. Each meeting the researcher gave the speaking material by Bamboo Dance approach in action. The action each meeting gave describing as follow:

\section{The first meeting:}

In the first meeting, the researcher gave material by applying Bamboo Dance step procedure:

a. presentation

The teacher introducesed a situation which contextualize the material to be thought, and then presented, and then the teacher gave instruction to the students to practice their language in retelling their experience. The teachers gave some topics to the students then choose one of them. namely: embarrassing moment, the first love, sweet memory etc. The teacher gave fifteen minutes to prepare their self and to organizing idea.

b. Practice

After gaving thirty minutes to prepare their self, the students practice by using their own words to retell their experience base on the topic that they chose.

c. Production

In this section, the students were encouraged to use the new language in a free way and find out another material either for their own purpose, and 
meanings or in similar context was introduced by the teacher and then presented in front of the class.

\section{The second meeting:}

\section{a. Presentation}

The teacher introduced a new material about telling story to the student and then presented it. After that, the teacher asksed the students to make telling story about self-introduction.

b. Practice

After making telling story, the teacher asked the students to practice their language in telling story orally.

c. Production

In this section, the teacher asked the students to find out another material or another topic of telling story and then practiced in front of the class.

\section{The Third meeting:}

a. presentation

In this section, the teacher explained about how to describe people/something to the students. Then the teacher gave fifteen minutes to the students to choose one object and then organized their idea.

b. Practice

In this section, the students practiced their new language in describing people or something.

c. Production

In this section, the students were encouraged to use the new language in a free way and found another material either for their own purpose, and meanings or in similar context that introduced by the teacher and then presented in front of the class.

\section{The fourth meeting:}

a. Presentation

The teacher introducesed a situation to contextualize the material to be thought, and then presented, and then the teacher gave instruction to the students to practice their language by using asking and giving opinion. namely: asking opinion, what do you think about internet? Giving opinion, I think internet is 
useful for people because it easy to get information. The teacher gave fifteen minutes to prepare their self and to organize idea.

b. Practice

In this section, the teacher asked to the students to found a couple, and then practiced these expressions with his/her couple (using asking opinion and giving opinion).

c. Production

In this section, the teacher asked to the students to find out another expression asking and giving opinion and then practiced in front of the class.

\section{Observation}

In this phase, the teacher observed the students' activity in learning process by using checklist observation to know the active students (active or not active). After applying Bamboo dancing in action for four meetings, the teacher gave evaluation to the students to know the students' speaking achievement in cycle I.

\section{Reflection}

The data value from evaluation is gathered for data analysis, so the researcher reflected data value evaluation in the cycle I to the cycle II.

\section{RESEARCH SUBJECT \& INSTRUMENT}

The researcher used the class VII.a at the first year of SMPN 4 Biringbulu gowa 2012 / 2013 Academic year that consisted of 24 students. The researcher used Tests to asses and examines the students' speaking fluency. The teacher gave test in each cycle to find out the improvement of the students' speaking fluency and the effectiveness of using Bamboo Dance to improve the students speaking fluency. The test instrument was gaven to the students they were: retelling experience, describing the picture.

\section{DATA COLLECTION \& ANALYSIS}

1. Observation; it aimed at finding out the students' participation during the teaching and learning process.

2. Interviewing; it aimed at finding out the students' responses during the teaching and learning process by interviewing students and teacher. 
3. Test; it aimed at finding out the students' improving speaking fluency and the effectiveness of Bamboo Dance in teaching speaking.

The data obtained from the oral test was analyzed through. Following step undertaken as follows:

1. Fluency (Smoothness)

\begin{tabular}{|l|l|l|}
\hline Classification & Score & Criteria \\
\hline Excellent & 6 & $\begin{array}{l}\text { Speaks without too great an effort with a fairly } \\
\text { wide range of expression. Searches for words } \\
\text { occasionally but only one or two unnatural } \\
\text { pauses. } \\
\text { Has to make an effort at times to search for } \\
\text { words. Nevertheless, smooth delivery on the } \\
\text { whole and only a few unnatural pauses. } \\
\text { Although he has to make an effort and search } \\
\text { for words, there are not too many unnatural } \\
\text { pauses. Fairly smooth delivery mostly. } \\
\text { Occasionally fragmentary but succeeds in } \\
\text { conveying the general meaning. Fair range of } \\
\text { expression. } \\
\text { Has to make an effort for much on the time. } \\
\text { Often has to search for the desired meaning. } \\
\text { Rather halting delivery and fragmentary. } \\
\text { Range of expression often limited. } \\
\text { Long pauses while he searches for the desired } \\
\text { meaning. Frequently fragmentary and halting } \\
\text { delivery. Almost gives up making the effort at } \\
\text { times. Limited range of expression. } \\
\text { Full of long and unnatural pauses. Very halting } \\
\text { and fragmentary delivery. At times gives up } \\
\text { making an effort. Very limited range of } \\
\text { expression. }\end{array}$ \\
\hline Very Poor & 5 & 1
\end{tabular}

(Heaton, J. B., 1975)

1. To calculate the mean score, the following formula was applied:

$$
\begin{array}{ll}
\overline{\mathrm{x}}=\frac{\sum \mathrm{x}}{\mathbf{N}} & \\
\text { Where: } \quad & \overline{\mathrm{x}}=\text { Mean score } \\
& \sum \mathrm{x}=\text { The sum of all score } \\
N & =\text { The number of students }
\end{array}
$$

(Gay, 1981) 
2. To convert the score (Heaton score) to the students' score, the formula which used as follows:

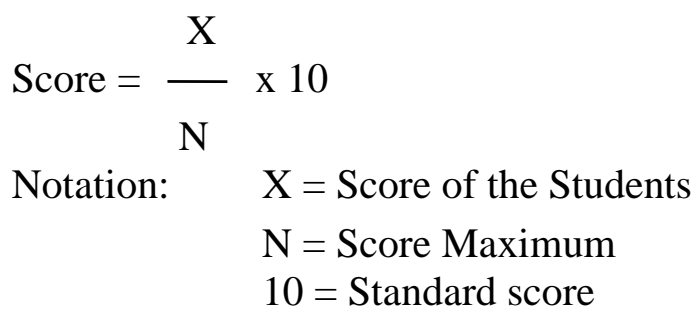

(Heaton, J. B., 1988, 101)

3. After collecting the data of the students, we could classify the score of the students. We could classify the score of the students into the following criteria:
a. 8.6 to 10 is classified as excellent
b. $\quad 7.6$ to 8.5 is classified as very good
c. $\quad 6.6$ to 7.5 is classified as good
d. $\quad 5.6$ to 6.5 is classified as fair
e. 3.6 to 5.5 is classified as poor
f. $\quad 0.0$ to 3.5 is classified as very poor

(Direktorat Pendidikan, 1999)

4. To know the increase of the students' by applying the following formula:

Increase $=\mathrm{X} 2-\mathrm{X} 1$

Where :

$$
\begin{array}{ll}
\mathrm{X} 1 & : 1^{\text {st }} \text { Cycle } \\
\mathrm{X} 2 & : 2^{\text {nd }} \text { Cycle }
\end{array}
$$

(Sudjana, 1999)

5. To calculate the percentage of the students' observation result, the formula which used as follows:

$$
\mathrm{P}=\quad \frac{\mathrm{Fq}}{4 \mathrm{xN}} \times 100
$$

Notation: $\quad \mathrm{P}=$ Percentage

$$
\begin{aligned}
& \mathrm{Fq}=\text { Frequency } \\
& \mathrm{N}=\text { The number of students }
\end{aligned}
$$


(Sudjana, 1999)

\section{FINDINGS AND DISCUSSION}

In this chapter the researcher explains about the findings and the discussion of the research. The findings of the research presents the general explanation about the action which the researcher did in the research and result of the increase of the students' speaking ability that covers the students' speaking fluency, and in the discussion of the research, the researcher explains about the further explanation of the findings.

\section{FINDINGS}

The finding of this A Cclassroom Action Research deals with the answer of the problem statement which is aimed to increase the students' speaking ability covers fluency. The findings consisted of the increase of the students' fluency in speaking ability and the students' activeness in teaching and learning process. The findings of the research detected that the use of Bamboo Dancing Method can increase the students' speaking ability in class VII.a SMPN 4 Biringbulu Gowa.

\section{The Increase of the Students' Speaking Fluency}

In increasing the students' speaking fluency through Bamboo Dancing Method in cycle I the students' fluency which deals with smoothness and self confidence was low. It was happen because the students were not accostumed in speaking English, then they didn't have any encourage in speaking. Therefore, most of them were difficult to speak fluently and still felt afraid to answer the question given to them.

In the cycle II the researcher efforted hard to increase the students' fluency deals with smoothness and self confidence through Bamboo Dancing Method intensively. The researcher encouraged the students to speak and the researcher trained the students to speak smoothness and self confidence. Therefore, most of the students finally could speak good in smoothness and self confidence, because they had any encourage in speaking and they were accostumed in speaking.

And the result in the cycle II the students' speaking fluency which deals with smoothness and self-confidence increase from 5.9 in the cycle I became 7.2 in the cycle II. And the teaching and learning process through Bamboo Dancing Method could increase the students' speaking fluency that covers with smoothness. The 
increase of the students' speaking fluency in smoothness can be seen in the following table clearly:

Table 1: The Increase of the Students' Speaking Ability

\begin{tabular}{|c|c|c|c|c|}
\hline \multirow{2}{*}{ No } & \multirow{2}{*}{ Indicators } & \multicolumn{2}{|c|}{$\begin{array}{l}\text { The } \\
\text { Score }\end{array}$} & \multirow{2}{*}{$\begin{array}{l}\text { Increase } \\
\text { Cycle I - Cycle } \\
\text { II }\end{array}$} \\
\hline & & Cycle I & $\begin{array}{l}\text { Cycle } \\
\text { II }\end{array}$ & \\
\hline 1. & Smoothness & 5.2 & 6.7 & 1.5 \\
\hline \multirow[t]{2}{*}{2.} & $\begin{array}{l}\text { Self } \\
\text { confidence }\end{array}$ & 5.9 & 7.7 & 1.8 \\
\hline & $\bar{X}$ & 5.5 & 7.2 & 1.6 \\
\hline
\end{tabular}

The table above proves that the Bamboo dancing Method in teaching and learning process can increase the students' speaking fluency in smoothness and selfconfidence after taking action in cycle I (5.5) which is classified as poor and cycle II (7.2) which is classified as good and it has achieved the standard score of SMP. The use of Bamboo Dancing Method in increasing the students' speaking fluency with smoothness and self-confidence can be seen clearly in the following table:

Table 2. The Increase of the Students' Speaking Fluency

\begin{tabular}{|l|l|l|l|l|}
\hline \multirow{2}{*}{ No } & \multirow{2}{*}{ Indicators } & \multicolumn{2}{|l|}{$\begin{array}{l}\text { The Student' } \\
\text { Score }\end{array}$} & Increase \\
\cline { 3 - 4 } & & Cycle I - Cycle \\
\cline { 3 - 4 } & & $\begin{array}{l}\text { Cycle } \\
\text { II }\end{array}$ & II \\
\hline 1. & Fluency & 5.9 & 7.2 & 1.3 \\
\hline
\end{tabular}

The table above indicates that there is the increase of the students' speaking ability from cycle I to cycle II, the Students' speaking ability in cycle I is categorized as poor (5.9) then the students' speaking ability increases in cycle I which is categorized as good (7.2). Therefore, the increase of students' speaking ability achievement from cycle I until cycle II is increasing significantly. The table above proves that the use of Bamboo Dancing Method in teaching and learning process can increase the students' speaking ability after taking action in cycle I and cycle II has been achieved the standard score. 


\section{The Result of the Students' Activeness in Teaching and Learning Process}

The result observation of the students' activeness in teaching and learning process toward the use of Bamboo Dancing Method in increasing the students' speaking ability the first grade students of SMPN 4 Biringbulu Gowa in class VII which was conducted in 2 cycles during 8 meetings is taken by the observer through observation sheet. It can be seen clearly through the following table:

Table 3: The Observation Result of the Students in Teaching and Learning Process

\begin{tabular}{|l|l|l|l|l|l|}
\hline & \multicolumn{3}{|l|}{ Meetings } & $\begin{array}{l}\text { Average } \\
\text { Score }\end{array}$ \\
\cline { 2 - 6 } & $\mathbf{1}^{\text {st }}$ & $\mathbf{2}^{\text {nd }}$ & $\mathbf{3}^{\text {rd }}$ & $\mathbf{4}^{\text {th }}$ & $\mathbf{5 2 . 8 6 \%}$ \\
\hline Cycle I & $42.70 \%$ & $52.08 \%$ & $50 \%$ & $66.66 \%$ & $\mathbf{5} \%$ \\
\hline $\begin{array}{l}\text { Cycle II } \\
\begin{array}{l}\text { Increase } \\
\text { Cycle } \\
\text { Cycle II }\end{array}\end{array}$ & $56.25 \%$ & $84.37 \%$ & $64.58 \%$ & $86.45 \%$ & $\mathbf{7 2 . 9 1 \%}$ \\
\hline
\end{tabular}

\section{DISCUSSION}

To make this discussion clear, the writer would like to explain in two parts; (1) Speaking ability can be improved by using Bamboo Dancing Method, (2) the effectiveness of using Bamboo Dancing Method to improve the students speaking ability thorough four indicators that have analyzed.

1. The speaking ability of the First Year Students' of SMPN 4 Biringbulu through Bamboo Dancing Method.

In the first cycle indicator of pronunciation had not improved yet, this item can be seen after testing and observing (speaking test, item 1,2 of first cycle), whereas just a view of number of students frequency, but in the second cycle this indicator has improvement, through testing and observing frequency of students added more than before especially in expressed their idea with using English (speaking test, item: 1, 2, 3 of second cycle)

The speaking ability of grammar means that how the students use correctly grammar in speaking, after testing and observing at the first cycle, students showed that almost of all students were lacks of using grammar (speaking test, item 1, 2, 3 of second cycle); the causes were students never 
study intensively about grammar. Because of this problem, in the second cycle the researcher tried to explain more about the using of correctly grammar and the result showed that there was improvement than the first cycle, whereas the number of students' frequency at the first cycle differs with the second cycle (speaking test, item 1, 2, 3 of second cycle).

In the first cycle, the speaking ability of vocabulary was not too bad than the other indicator like indicator of pronunciation and grammar. The result can be seen after testing and observing (speaking test, item 1, 2, of first cycle), whereas the number of students in average score was fifty percent although some of the students are lack of vocabulary but this item made the researcher happy although there was still aspect need to be improved in the next cycle.

After testing and observing in the second cycle, the indicator of vocabulary really has a good improvement. In this section almost the students know many vocabularies whereas just views of students are poor of vocabulary (speaking test, item 1, 2, 3 of second cycle).

Students' fluency in first cycle was very lack, whereas just twenty five percent of students got average score and other was poor and very poor, the causes was the students' habit of using Indonesian language (speaking test, item 1, 2, of first cycle). Because of this problem made the researcher worked hard in the second cycle to solve it. In the second cycle after testing and observing the result was show that there was a maximal improvement than the first cycle. The indicator of vocabulary was maximal because the researcher and collaborator gave maximal chance to the students to try and try in speaking (speaking test, item 2, 3 of second cycle).

2. The effectiveness of using Bamboo dancing Investigation Approach in improving students' speaking ability of the first year students' SMPN 4 Biringbulu.

From the four indicators that have analyzed, namely: fluency and also the students' learning activities, creativity, feeling happy, and interaction to each other showed that Bamboo dancing Group Investigation Approach was very effective in improving students' speaking ability. 
It is very reasonable if bamboo dancing method approach can improve the students speaking ability because it is signed by the learning process is focused on the students and it is more constructivist, the situation of the learning process is more conducive, in the learning process the students seem active and creative, and the condition of the learning process feels enjoyable. It is consistent with Samawi's statement (2006).

The findings or results of this research are also supported by many Researchers. According to Rusmiati (2009:57) the students' attitude towards the application of bamboo dancing was interested, so they are motivated to study English. According to Nurbaya (2009:55) using Socio-Affective Learning Strategies through Bamboo Dancing can improve the students' motivation in learning English. The main point in this study was to improve the students' speaking ability and overcome the students' problems in speaking using Bamboo Dancing. It was happened because the students' achievements and performances improve from the first cycle to the second cycle. Even though, it still needs some stabilization, but it has to be stopped because is has limited time and all students have passed in this lesson and get good scores. Therefore, if there is someone wants to continue this research in the next time, it will be great and the researcher will really appreciate it.

The result of the students' observation in teaching and learning process improved fluency through the use of bamboo dancing in increasing the students' speaking ability. It is proved by the improvement of the students' activeness in cycle I namely $52.86 \%$ become $72.91 \%$ in cycle II. Based on the explanation above, the writer concludes that the use of Bamboo dancing can significantly improved the students' speaking ability in terms of fluency. Beside that the use of Bamboo dancing in improving the students' speaking ability can make students of class VII exact at SMPN 4 Biringbulu Gowa active in learning English language.

\section{BIBLIOGRAPHY}

Arikunto, suharsini (2005). Procedure Penelitian: Suatu Pendekatan Praktek. Jakarta: PT. Rineka Cipta. 
Birney. D. (1976). Teaching Oral English. New York. Inc.Longman ClarH. Herbert. At all (1977). Psychology and Language. New York: hacant Bace Javo Vich Publisher.

Depdikbud, 1989. Garis- Garis Besar Program Pengajaran (Kurikulum 1994) Untuk Sekolah Menengah Umum. Depdikbud

Djamarah, Syaiful, Zain, Aswan (2002). Srategi abelajar amengajar. Jakarta: PT. Rineka Cipta.

Gay,L.R.(1981). Education Research: Competencies for Analysis and Application. Colombua: Clurles E. Mrril Publishing Company.

Harmer, Jeremy (2001). The Practice in English Teaching. New York: Longman.

Heaton, J. B. 1975. Writing English Language Test. New York: Longman Inc.

Hornby, A.S. (1995). Oxford Advance Learners' Dictionary. London: Oxford University.

Longman. 1995. Contemporary English Dictionary. New York. Longman English Contemporary Press.

Webster.1998. Encyclopedic can bridge Dictionary of Language. New York, Portland House. 